https://doi.org/10.46813/2020-130-146

\title{
MAGNETRON DISCHARGE INTENSIFICATION FOR EFFECTIVE DEPOSITION OF COATINGS FROM DIFFICULT SPRAY METALS
}

\author{
A.G. Chunadra ${ }^{1}$, K.N. Sereda ${ }^{1}$, I.K. Tarasov ${ }^{1,2}$, Y.A. Vereshchaka ${ }^{1}$ \\ ${ }^{1}$ V.N. Karazin Kharkiv National University, Kharkiv, Ukraine; \\ ${ }^{2}$ Institute of Plasma Physics NSC “Kharkov Institute of Physics and Technology”, Kharkiv, Ukraine \\ E-mail: agchunadra@gmail.com
}

The work is devoted to improvement of magnetron discharge parameters based on a standard magnetron sputtering system (MSS) of the MAG-5 type with an additional anode magnetic trap for discharge electrons in the conditions of localization of the discharge zone in the gap between electrodes to prevent charged particles losses. Possibilities of such configuration of MSS for depositing of coatings of materials with low coefficient of sputtering (tungsten) are investigated. The increase of the coating rate has been demonstrated. The mass of the deposited tungsten increased by more than $35 \%$ compared to the use of the same MSS without additional anode magnetic trap.

PACS: 51.50.+v, 52.25.Jm

\section{INTRODUCTION}

Research on increasing the efficiency of magnetron sputtering by sharing both the combined stationarypulse mode of magnetron discharge and the use of magnetic insulation of the anode are important for the development of coating technologies, which, in turn, is required in many fields of science and technology. Deposition of coatings are resistant to corrosion, high temperatures, mechanical and radiation damages is one of the advanced tasks of modern science and technology. Such coatings-are applied in scientific researches as well as many fields of industry $[1,2]$. For example, tungsten $(W)$ coatings applied in radiation protection technologies. It should be note that $\mathrm{W}$ is not a structural metal due to its high melting point of $3695 \mathrm{~K}$. Most tungsten products are obtained by spilling powder or producing alloys. Solid-tungsten alloyed by nickel, iron, copper and other metals, as well as a suspension of tungsten powder with other materials in a polymer base, are used for radiation protection. Tungsten coatings deposited by magnetron sputtering are more prospected and helpful for application in scientific installations for the study of radioisotopes and/or for fusion. However, thickness of such tungsten layer should be sufficiently increased. From this reason, efficiency of tungsten coatings deposition need to increase.

This paper proposes the way to increase of the magnetron sputtering efficiency by using magnetic insulation of the anode with a change of magnetic configuration in the near anode space. The aim of the work is evaluation of magnetic configuration of magnetron system with as well as without a near anode additional magnetic trap. The investigation of the voltage-ampere characteristics of the discharge was performed for choosing better magnetic configurations for increasing of efficiency coating deposition in the magnetron sputtering system.

\section{EXPERIMENTAL EQUIPMENT}

The computer program FEMM 4.0 was used to calculate the topology of magnetic fields in the bit interval of the magnetron sputtering system (MSS). Fig. 1 shows the configuration of the vacuum magnetic field of the planar magnetron sputtering system MAG-5. Analysis of the magnetic fields topology showed that the MAG-5 MSS is quite well balanced. However, a significant number of magnetic power lines near the axis of the system close at infinity, which leads to the loss of electrons from the discharge.

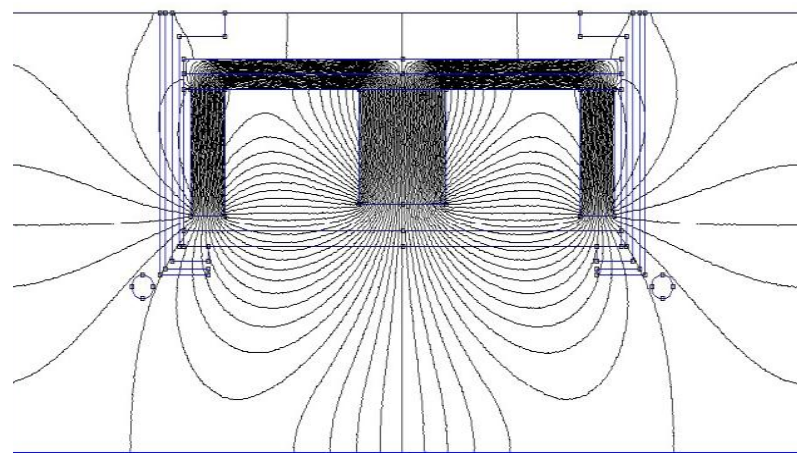

Fig. 1. The configuration of the vacuum magnetic field of the planar magnetron sputtering system MAG-5

Additional external anode magnetic conductor was installed to MSS MAG-5 for eliminating the loss of electrons from the discharge. The balancing of the MSS is also improved. As result an anode magnetic trap for electrons of discharge plasma was created. By gradually changing the position and geometric dimensions of the magnetic circuit, as well as the location and parameters of permanent magnets, the optimal design and location of the magnetic circuit is obtained.

Fig. 2 shows the configuration of the vacuum magnetic field of the planar magnetron sputtering system MAG-5 with an additional anode magnetic circuit. The formation of an anode magnetic trap led (see marked circle in Fig. 2) to the imbalance of the MSS in the peripheral region, which would contribute to the loss of electrons from the discharge. 


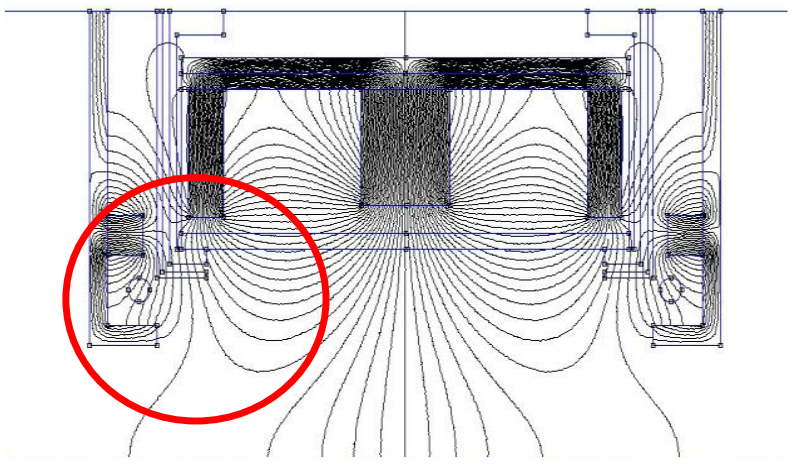

Fig. 2. The configuration of the vacuum magnetic field of the planar magnetron sputtering system MAG-5 with an additional anode magnetic circuit

By gradually selecting the location of the permanent magnets of the anode magnetic system, it was possible to achieve the elimination of MSS imbalance in the peripheral region. Fig. 3 shows the configuration of the vacuum magnetic field of the planar magnetron sputtering system MAG-5 with an additional anode magnetic circuit without imbalance in the peripheral region (see marked circle in Fig. 3).

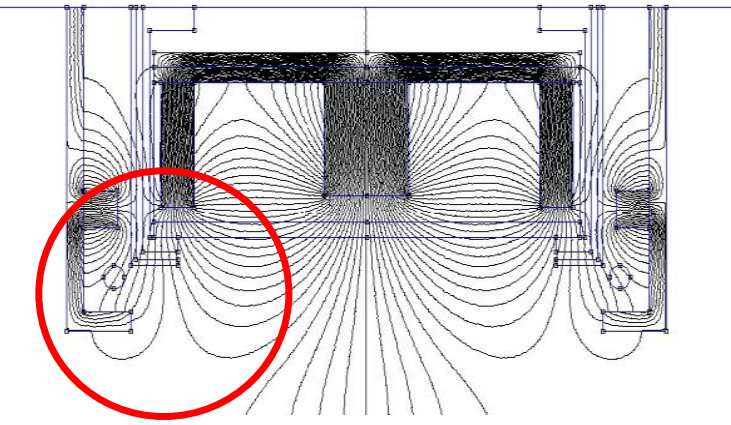

Fig. 3. The configuration of the vacuum magnetic field of the planar magnetron spraying system MAG-5 with boat anode magnetic wire without imbalance in the peripheral region

However, this configuration does not completely avoid the loss of electrons from the discharge, because some magnetic lines of force, although closed on the magnetic circuit, but from the outside. To solve the problem of eliminating the residual imbalance of the system, it was decided to increase the degree of coverage by the magnetic conductor of the additional anode magnetic systems of the cathode block MSS.

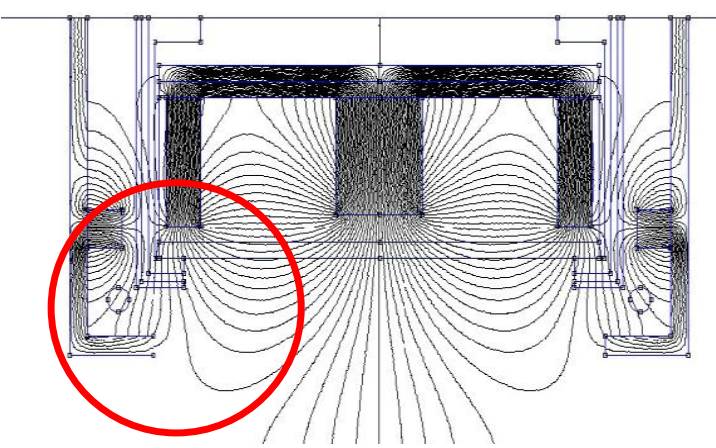

Fig. 4. The final configuration of the vacuum magnetic field of the planar magnetron sputtering system MAG-5 with an additional anode magnetic circuit
Fig. 4 shows the finally accepted configuration of the vacuum magnetic field of the planar magnetron sputtering system MAG-5 with an additional anode magnetic circuit. The imbalance of the MSS in the peripheral region was completely eliminated; the optimal configuration of the anode magnetic trap for discharge electrons was achieved.

Based on the data obtained as a result of the calculations, the design of the location in the vacuum chamber of MSS MAG-5 with an additional anode magnetic circuit was carried out. Fig. 5 shows a front section of a planar magnetron sputtering system MAG-5 with a boat anode magnetic circuit.

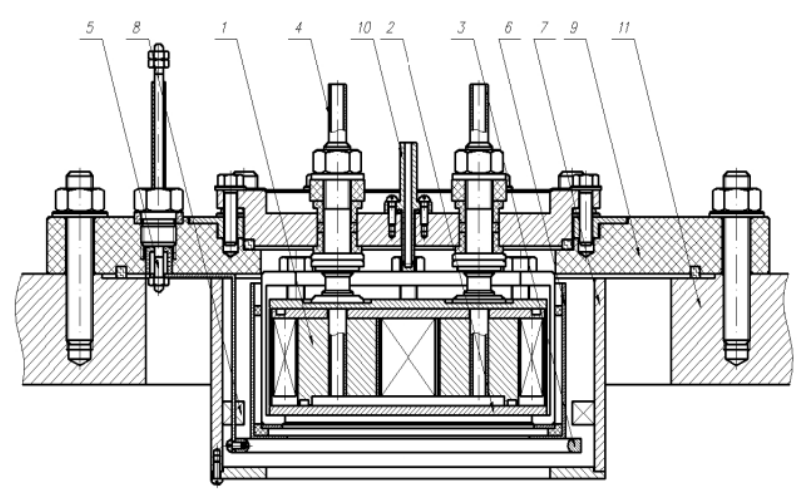

Fig. 5. Frontal section of the planar magnetron sputtering system MAG-5 with a boat anode magnetic circuit: 1 -MSS MAG-5; 2 - tungsten target;

3 -anode; 4 -conclusions of water cooling and power supply of the cathode assembly; 5 - power supply output of the anode; 6 -isolated screen-guard of the cathode unit; 7 - additional anode magnetic circuit; 8 - magnets that create an additional anode magnetic field; 9 - the main insulator, which provides the ability to operate the system in conditions of non-potential ground; 10 - a gas supply branch pipe;

11 - the wall of the vacuum chamber

Careful electrical insulation of electrical inputs of MSS electrodes provided the possibility of system operation in non-potential ground with power supply of electrodes of discharge "+" - anode, "-" - cathode, in order to localize the discharge region between the electrodes of discharge and prevent loss of charged particles from gas discharge plasma.

\section{RESULTS OF EXPERIMENTS AND DISCUSSION}

In the experiments, the volt-ampere characteristics of a stationary magnetron discharge in MSS based on MAG-5 were measured with and without an additional anode magnetic field. Using a double probe, comparative measurements of electron temperature and gas discharge plasma ion density in the MSS were made in both configurations. The method of probe measurements is described in detail in the paper [3].

The test deposition of tungsten coatings was also performed on copper samples with/without an additional anode magnetic trap for discharge electrons and using a standard MSS configuration. The efficiency of the coating process was evaluated by weighing the samples 
before and after deposition. The obtained weight gain $\Delta m$ divided by the time for which this coating was applied, allowed obtaining the value of the rate of coating using MSS with an additional anode magnetic system compared to standard MSS.

Fig. 6 shows the obtained volt-ampere characteristics of the stationary magnetron discharge in MSS on the basis of MAG-5 with/without of additional magnetic insulation of the anode.

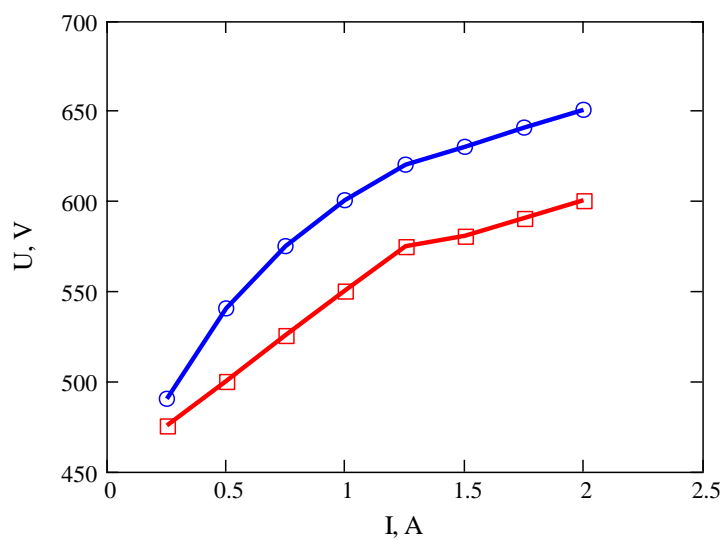

Fig. 6. Volt-ampere characteristics MSS MAG-5.

The red line corresponds to MAG-5 without additional magnetic insulation of the anode, and the blue

$M A G-5$ - using an additional magnetic circuit to create an anode magnetic trap

The use of an additional anode trap causes an increase of the discharge combustion voltage in the MSS by about $50 \mathrm{~V}$ at the same discharge current as without additional anode magnetic field. Increasing the voltage at the discharge gap, in turn, contributes to increasing the energy of the flow of gas ions to the target cathode of the MSS and, as a result, increases the efficiency of the sputtering process of the target material.

The temperature of the electrons and the concentration of ions were $\mathrm{T}_{\mathrm{e}}=4.11 \mathrm{eV}$, $\mathrm{n}_{\mathrm{i}}=1.033 \cdot 10^{11} \mathrm{~cm}^{-3}$, correspondently when using MSS without magnetic isolation. The growth rate of the mass of the deposited tungsten coating achieved $\Delta \mathrm{m}=0.17 \mu \mathrm{g} / \mathrm{s}$.

The electron temperature and ion concentration increased up to $\mathrm{T}_{\mathrm{e}}=7.506 \mathrm{eV}, \mathrm{n}_{\mathrm{i}}=5.868 \cdot 10^{11} \mathrm{~cm}^{-3}$, correspondently, at application of an additional anodic magnetic field. The growth rate of the mass of the deposited tungsten coating increased till $\Delta \mathrm{m}=0.23 \mu \mathrm{g} / \mathrm{s}$. The obtained results show that the use of an additional anode magnetic trap in the MSS under conditions of localization of the discharge zone in the gap between electrodes and prevention of loss of charged particles from the volume of gas-discharge plasma significantly increases (by about $35.3 \%$ ) the rate of mass growth of deposited tungsten although tungsten has a very low sputtering ratio $(\mathrm{S}(\mathrm{W})=0.6)$.
The further direction of development that exists for this system is to use the MSS based on the MAG-5 with magnetic insulation of the anode together with the pulse power source for its use in the combined stationarypulse discharge [4]. The results obtained in previous works allow us to expect an even higher rate of application of tungsten coatings, with high quality coatings (surface adhesion to the substrate, surface structure and homogeneity, resistance to thermal and mechanical damage), which can be used in further scientific and technical research.

\section{CONCLUSIONS}

In this paper, the prospects of localization of the gas discharge zone and the use of an additional anode magnetic system for holding charged particles of gasdischarge plasma in MSS without changes to standard devices and without additional power supplies are investigated.

The use of an additional anode trap for discharge electrons leads to an increase in the voltage at the discharge gap, which increases the energy of the flow of gas ions at the target cathode MSS and, consequently, increases the efficiency of the process of spraying the target material.

Comparison of the results of the study of the deposition rate of tungsten coatings show that the use of additional anode magnetic trap for discharge electrons in MSS in terms of localization of the discharge zone in the gap between electrode and prevent loss of charged particles from the volume of gas discharge plasma significantly increases (approximately 35.3\%) the growth rate of the mass of precipitated tungsten.

\section{REFERENCES}

1. R.D. Arnell, P.J. Kelly. Recent advances in magnetron sputtering // Surf. Coat. Technol. 1999, v. 112 , p. 170-176.

2. S. Schiller, U. Heisig, G. Beister, et al. Deposition of hard wear-resistant coating by reactive d.c. plasmatron sputtering // Thin Solid Films. 1984, v. 118, № 3, p. $255-270$.

3. A.G. Chunadra, K.N. Sereda, I.K. Tarasov. Probe measurements of parameters of dense gasmetallic plasma in the inhomogeneous magnetic field of a planar magnetron discharge // Problems of Atomic Science and Technology. Series «Plasma Physics» (118). 2018, № 6, p. 252-254.

4. A.G. Chunadra, K.N. Sereda, I.K. Tarasov, A.A. Bizukov, A.I. Girka. Features of coatings deposition in combined stationary-pulsed operation mode of the magnetron sputtering system // Problems of Atomic Science and Technology. Series «Plasma Physics» (107). 2017, № 1 (23), p. 227-230.

Article received 30.09.2020 


\section{ИНТЕНСИФИКАЦИЯ МАГНЕТРОННОГО РАЗРЯДА ДЛЯ ЕФФЕКТИВНОГО ОСАЖДЕНИЯ ПОКРЫТИЙ С ТРУДНОРАСПЫЛЯЕМЫХ МЕТАЛЛОВ}

\section{А.Г. Чунадра, К.Н. Середа, И.К. Тарасов, Е.А. Верещака}

Работа посвящена исследованиям улучшения параметров магнетронного разряда на базе стандартной магнетронной распылительной системы (МРС) типа МАГ-5 с дополнительной прианодной магнитной ловушкой для электронов разряда в условиях локализации зоны разряда в межэлектродном промежутке для предотвращения потерь заряженных частиц из плазмы. Исследованы возможности такой конфигурации МРC для нанесения покрытий с материалов, имеющих низкий коэффициент распыления (вольфрам). Продемонстрировано повышение скорости нанесения покрытий и достигнут прирост массы нанесенного вольфрама больше, чем на 35 \% по сравнению с использованием той же МРС без создания дополнительной прианодной магнитной ловушки.

\section{ІНТЕНСИФІКАЦІЯ МАГНЕТРОННОГО РОЗРЯДУ ДЛЯ ЕФЕКТИВНОГО ОСАДЖЕННЯ ПОКРИТТІВ 3 ВАЖКОРОЗПОРОШУВАНИХ МЕТАЛІВ}

\section{А.Г. Чунадра, К.М. Середа, І.К. Тарасов, С.А. Верещцака}

Робота присвячена дослідженням покращення параметрів магнетронного розряду на базі стандартної магнетронної розпорошувальної системи (МРС) типу МАГ-5 з додатковою прианодною магнітною пасткою для електронів розряду в умовах локалізації зони розряду в міжелектродному проміжку для запобігання втрат заряджених частинок з плазми. Досліджено можливості такої конфігурації МРС для нанесення покриттів 3 матеріалів, які мають низький коефіцієнт розпорошення (вольфрам). Продемонстровано підвищення швидкості нанесення покриттів, та досягнутий приріст маси нанесеного вольфраму більше, ніж на 35 \% у порівнянні з використанням тієі ж МРС без створення додаткової прианодної магнітної пастки. 
